\title{
Character, Discipline, Law: Courts Martial in World War I
}

\author{
MARK FINNANE \& YORICK SMAAL
}

Courts martial were as ubiquitous in the experience of World War I as criminal courts in civil life, yet they remain largely neglected in the Australian war historiography. Their remarkable evidentiary record, transmitted from the field of battle into the custody of the Attorney-General, has been used to highlight wartime dimensions of individual character and collective discipline. In this article, we review the uses of the courts martial in those respects. We note the significance of Australian exceptionalism in this military domain, and consider the potential of an approach that treats the court martial as a legal event.

Australians serving abroad in World War I as part of the British Imperial forces were in a privileged position. Frequently criticised for their indiscipline, Australian soldiers were immune from the death penalty, even where the sentence was awarded at court martial for offences under the Army Act, including mutiny, desertion and treating with the enemy. ${ }^{1}$ Immunity followed from the Commonwealth government's insistence that Australian soldiers serving in the British Army would be subject to the Imperial Army Act, except when this was inconsistent with the Defence Act 1903. That legislation not only restricted the number of offences for which the death penalty might be applied, but made execution dependent on the approval of the Governor-General, effectively subjecting that decision to the advice of

We would like to thank Lee Butterworth for research assistance; Tim Sherratt (University of Canberra) for his expertise and generosity in sharing the archive metadata that got us started; and Peter Stanley and John Connor as well as the anonymous referees for their suggestions.

This research was supported by the Australian Research Council, FL130100050 and Griffith University, Arts Education and Law Group Research Grant (2017).

No potential conflict of interest was reported by the authors.

${ }^{1}$ Robert Charles Stevenson, The War with Germany, Centenary History of Australia and the Great War, vol. 3 (Melbourne: Oxford University Press, 2015), 122-26; Richard Glenister, 'Desertion without Execution: Decisions That Saved Australian Imperial Force Deserters from the Firing Squad in World War I', (BA Hons thesis, La Trobe University, 1984); Dianne Kaye De Bellis, 'Stories of Australian Deserters in World War' (PhD thesis, University of South Australia, 2014); Edward John Garstang, 'Crime and Punishment on the Western Front: The Australian Imperial Force and British Army Discipline' (PhD thesis, Murdoch University, 2009); Christopher Pugsley, On the Fringe of Hell: New Zealanders and Military Discipline in the First World War (Auckland: Hodder \& Stoughton, 1991). 
cabinet. ${ }^{2}$ Throughout 1917, Lieutenant-General Sir William Birdwood, commander of the Australian forces, complained to Governor-General Sir Ronald Munro Ferguson about the disciplinary problem posed by death penalty immunity, the ramifications of which were only fully realised when Australian troops arrived in France. ${ }^{3}$ Ferguson agreed that conditions on the Western Front highlighted the challenge. If "the geography of Gallipoli obviated the need for the death penalty', he observed, the desertion and absences that had since become common required something more than 'the "buttering up" policy' which had proved ineffective. ${ }^{4}$

Remarkably, and in the face of repeated political and military command pressure from the imperial government, the Australian government resisted demands to remove distinctions among the soldiers of the dominions. In May 1916, and February and August 1917, the British government and Birdwood repeatedly sought to persuade the Australian Government of the need for 'something more'. By cablegram the Commander-in-Chief Sir Douglas Haig warned 'that unless Commonwealth government agreed to place their troops under Army Act without any restrictions as regards death penalty fighting efficiency of these divisions will deteriorate to an extent which may gravely affect success of our arms'. The Army Council compared the statistics of Australian indiscipline, expressed in figures for desertion and absence without permission, with those of the other dominion and home forces. Haig had 'endeavoured so far as possible to avoid drawing attention of rest of armies to special position of Australian forces but it is now beginning to be generally known and commented on and is likely to promote bad feeling amongst troops'. ${ }^{5}$ Resisting the pressure, the Commonwealth government prevaricated when it could, but firmly resisted change when it was no longer able to delay. ${ }^{6}$ In August 1917, Federal Cabinet decided that 'at this

\footnotetext{
${ }^{2}$ National Archives of Australia (hereafter NAA), A6006, 1917/7/25, Application of Imperial Army Act to AIF (1917); NAA, M367/1 403/8/354, Application of Death Penalty in the AIF.

${ }^{3}$ Australian War Memorial (hereafter AWM), DRL/3376, Birdwood collection, RCDIG0000041, Birdwood to Ferguson, letter (4 April 1917), also letters (31 March1917) (18 August 1917) (20 August 1917).

${ }^{4}$ AWM, 3DRL/3376 6/2, Ferguson collection, RCDIG0000038, Ferguson to Birdwood, letter (2 September 1917).

${ }^{5}$ NAA, M367/1 403/8/354, Application of Death Penalty in the AIF, Cablegram of Secretary of State for Colonies (23 August 1917), and see Appendix B in De Bellis, 'Stories of Australian Deserters in World War'.

${ }^{6}$ John Connor, Anzac and Empire: George Foster Pearce and the Foundations of Australian Defence, Australian Army History Series (Melbourne: Cambridge University Press, 2011), 106-7.
} 
juncture' the government would not amend the Defence Act 'to conform with the Army Act in reference to sentence of death as punishment for desertion'?

The very exceptionality of the Australian court martial in respect of punishment may be a reason for the limited attention to it in the extensive Australian war literature. Many decades after the war, campaigns for the retrospective pardon of soldiers executed in World War I contributed significantly to the now rich historiography of courts martial in other places. ${ }^{8}$ By comparison, the relatively mundane outcomes of Australian military justice have relegated the court martial in World War I to the fringes of Australian military history. Despite the fact that more than 22,000 Australian courts martial were held between 1914 and 1919, the topic receives limited attention. As we discuss in this article, the court martial, where it has received notice, has been usually approached as an occasion to address questions of character including criminal or other personal dispositions at key moments on particular battle fronts, or as an element of military administration, especially with respect to discipline. Rarely do historians consider it as a legal event, measured against standards of fairness and procedure in civil society. Can the court martial be recovered as an element of the broader history of criminal law in its modern guise? By examining some aggregated features of process and outcomes, we highlight the value of the Australian court martial archive in addressing that question. We propose that the court martial deserves renewed investigation, supplementing its existing treatment as a symptom of failure in character or discipline.

\section{Character}

In a war literature so focused on the elevating qualities of courage in the face of combat and ordeal, it is scarcely surprising that the practice of military law and courts martial should be readily linked to judgements of character and worth. Indeed, it is notable that estimates of

\footnotetext{
${ }^{7}$ NAA, M367/1 403/8/354, G F Pearce, minute (25 July 1917). Pearce's minute is on a page which records the similar recommendation of Solicitor-General Robert Garran and is annotated 'For Cabinet'. See also Connor, 106-7; Stevenson, 126; Glenister; Charles Bean, Official History of Australia in the War of 1914-18 (Sydney: Angus \& Robertson, 1921).

${ }^{8}$ Cathryn Corns and John Hughes-Wilson, Blindfold and Alone: British Military Executions in the Great War (London: Cassell, 2005); Pugsley; Anthony Babington, For the Sake of Example: Capital Courts-Martial, 1914-1920 (London: Leo Cooper in association with Secker \& Warburg, 1983).
} 
character enliven revisionist war historiography as much as conventional accounts - in both cases, the evidence generated by a court martial is used to attest to personal worth or disgrace. An exhaustive review is not possible here, but we note the role played by character in the influential official history by Charles Bean. He framed the 'absence of the death penalty' as a challenge to Australian performance on the Western Front, highlighting desertion as a disciplinary problem created by an insufficient deterrent. In this respect, he sided with the generals, like Birdwood, who wanted the government to make the death penalty available for Australian soldiers. For Bean, the disciplinary system failed in the face of those 'few men of a character recognised by their comrades as well as by their officers to be worthless to any community', and who knew that they could breach military discipline without risking execution. ${ }^{9}$ Appraisal of character inflected disciplinary decision-making even below the threshold of offences warranting execution - Colonel John Monash (as he was then) related a compelling example on the eve of Gallipoli. He lamented the 'very bad case' of a private serving in the Post Office Corps facing court martial for stealing letters, including remittances that he converted to his own use. After the man was convicted, Monash ordered he be returned to Australia and discharged. ${ }^{10}$ It was, Monash said, 'simply unthinkable that a man of such bad character should be allowed to accompany honest comrades in active service'. ${ }^{11}$

A different approach to character highlights the potential of court martial sources for the development of more critical, even iconoclastic, accounts of the war experience. Seeking to throw a cold eye on the mythology surrounding the 'Anzac hero', the very title of Peter Stanley's examination of the transgressive side of the soldiers' war, Bad Characters, ranges widely over the lessons to be drawn from the evidence found in sources like the courts martial. Stanley's perspective is nevertheless respectful of the trials and tribulations of war service, less inclined than Bean to condemn the 'worthless' than to pity them. ${ }^{12}$ Shifting focus to the battlefront, Dale Blair's sympathetic but thoroughly revisionist account of the 1st Battalion, Dinkum Diggers, emphasises evidence of failure, fear, personal shortcoming and

\footnotetext{
${ }^{9}$ Bean, Official History, vol. 5, 28.

${ }^{10}$ NAA, B2455: Morgan, Sidney Hamilton, fol. 36.

${ }^{11}$ AWM, 3DRL/2316, Monash collection, RCDIG0000580, Monash to Colonel Hector Clayton, letter (8 April 1915).

${ }^{12}$ Peter Stanley, Bad Characters: Sex, Crime, Mutiny, Murder and the Australian Imperial Force (Sydney: Pier 9, 2010).
} 
outright resistance as grounds for questioning the iconic view of the Australian soldier, though the book notices courts martial only in passing. ${ }^{13}$ For others, character offers sensationalism, with courts martial evidence forming part of a narrative focussed on criminal careers and moral depravity, but also providing an opportunity for tracing pathways to redemption through bravery in battle. ${ }^{14}$ Indeed one of the most influential texts of the modern Australian literature, Bill Gammage's The Broken Years, offers just such a view of the relationship between court martial, crime and character in stories that capture the larrikin element as well as the nobility of Australian soldierly endeavour. ${ }^{15}$

Closer attention to the biographies of those who ran afoul of military law, and no doubt of those who avoided it, may reward us with other kinds of criminal narrative. The digitisation by the National Archives of Australia of the courts martial archive increases the possibility of tracking the prewar and postwar careers of those tried by military law. ${ }^{16}$ Recruitment was an opportunity for many to find their keep as well as a role. Was it for some a chance to set aside a best forgotten past? On some attestation forms, recruits were asked whether they had ever 'been convicted by the Civil Power'. Cecil Madden, a 36-year-old Ipswich carpenter, firmly answered 'No' when he enlisted in the 1st Battalion in August 1915. But an inquiry to the NSW Prisons Department would have revealed at least ten previous court appearances, including a 12-month term in Goulburn prison in 1904 for assault. ${ }^{17}$ Six months after enlistment he was involved in the Liverpool mutiny, joining hundreds of other soldiers in leaving the Liverpool and Casula camps and travelling by train into the city of Sydney where they created mayhem for some time before being brought under control. Some, like Madden, were arrested and charged by civilian police before later facing

\footnotetext{
${ }^{13}$ Dale James Blair, Dinkum Diggers: An Australian Battalion at War (Melbourne: Melbourne University Press, 2001).

${ }^{14}$ Russell Robinson, Khaki Crims and Desperadoes (Sydney: Pan Macmillan Australia, 2014).

${ }^{15}$ Bill Gammage, The Broken Years: Australian Soldiers in the Great War (Canberra: Australian National University Press, 1974).

${ }^{16}$ Bruce Scates, 'How War Came Home: Reflections on the Digitisation of Australia's Repatriation Files', History Australia 16, no. 1 (April 2019): 190-209.

${ }^{17}$ Mark Finnane, Andy Kaladelfos, Alana Piper,Yorick Smaal, Robyn Blewer and Lisa Durnian, et al The Prosecution Project Database, https://app.prosecutionproject.griffith.edu.au/ (2 March 2020, (hereafter PP)
} Trial \#317517; for his conviction at Newcastle Quarter Sessions 1904 Daily Telegraph 25 Nov 1904. and his long NSW conviction record (including two public order offences after his enlistment) see https://www.records.nsw.gov.au/index_image/2232_a006_a00603_5975000087r 
court martial. Madden was acquitted by court martial on the mutiny charge after earlier pleading guilty in the Central Police Court to a charge of 'behaving in a riotous manner'. On release from a three month sentence in Long Bay prison, he was discharged from army service in May 1916. Six months later he re-enlisted, again falsely stating he had not been convicted in a civilian court. In 1917 he joined troops of the 46th Battalion serving in France where he was killed in action in August the following year. Madden's patchy history of infraction and his confected life-histories were not enough to warrant a refusal of war medals, issued to his family in $1921 .^{18}$

Not all attestation forms included the 'previous conviction' question - and so William John Henry Banks was not required to disclose his prior criminal history at enlistment in August 1916. His field general court martial in June 1919 for killing a French bar-owner was the most serious charge he ever faced, and his five year sentence the heaviest he ever received. His war service was marked by repeated disciplinary offences including two earlier courts martial. His criminal life in uniform continued a pattern established before his enlistment, a familiarity with prison totalling 2 years and 7 months served for a range of fraud, false pretences and stealing offences dating back to 1910. Like many others prosecuted for serious offences by court martial late in the war, his return to Australia also brought early release. But nothing in his career before or during the war prepared him for a more settled life. He appears periodically in Pentridge prison records throughout the following decades until 1947. ${ }^{19}$

Only a large-scale exercise in data linkage might bring us closer to understanding whether these individual stories are patterned rather than idiosyncratic. In that respect, our historical appreciation is for the time being constrained by the kind of information barriers that separated wartime recruitment from prewar criminal records. An infamous case is that of one of the few Australian soldiers executed during the war, though not because of court-

\footnotetext{
${ }^{18}$ NAA, B2455 (1966287), Madden C. E.; for the courts martial, NAA, A471, 1143 (99620); for the 1904 assault Daily Telegraph 25 November 1904, 8, http://nla.gov.au/nla.news-article237834096. For the context of the Liverpool 'mutiny' see e.g. Blair, 40-44.

${ }^{19}$ PP Trial \# 426152; for his war record: NAA, B2455, Banks W. J. H; for his 1914 Victorian conviction see PP Trial \# 116969, http://app.prosecutionproject.griffith.edu.au/web/public-search/search/116969. (Depending on the source of data, not all Prosecution Project trial records are currently available by public search - where they are, the relevant url link is provided as in this case).
} 
martial. When he enlisted in Adelaide in December 1916, the man known as Arthur Geoffrey Olding stated that he had not been convicted 'by the Civil Power'. But this was a man who 'thought by going to the front I could wipe out the past', as he later confessed. He had reached no further than the Machine Gun Depot at Seymour in Victoria when he went absent without leave in September 1917 and became subject to an arrest warrant for desertion. In November 1917 he murdered a mother and daughter at nearby Trawool. Only subsequently did it become clear that, as George Farrow Blunderfield, he had a violent criminal record in Western Australia, including convictions in 1900 for the rape of a child and in 1909 for attempted murder. Porous borders and limited police technologies meant that, after escaping from Rottnest Island prison in April 1914, Blunderfield readily made his way to South Australia and assumed a new identity. His conviction for the 1917 double murder prompted some political debate over the use of the death penalty in civil and military jurisdictions, but his appalling record meant that his status as a soldier could not save him from execution at Old Melbourne Gaol in April $1918 .^{20}$ In mute testimony to a failed life, his attestation papers record that he was not eligible for the pamphlet 'Where the Australians Rest', nor for an appearance on the Memorial Scrolls. ${ }^{21}$

When Bean judged some disciplinary infractions as a symptom of deeper character flaws, he was concerned primarily with how these flaws affected military efficiency and battlefield valour. But as we see in some of the narratives reconstructed from linking military records to prewar antecedents, the court martial records become elements in a longer life story, where wartime experience failed to rescue a soldier from his own past.

\section{Discipline}

For Bean, the evidence of 'crime', as it was known through courts martial, was testimony to the poor character of the 'worthless'. But he suggested also that it could be read another way

\footnotetext{
${ }^{20}$ For Oldring/Blunderfield see PP Trial \# 558761, http://app.prosecutionproject.griffith.edu.au/web/publicsearch/search/558761; PP Trial \# 1766, http://app.prosecutionproject.griffith.edu.au/web/publicsearch/search/1766; PP Trial 1240, http://app.prosecutionproject.griffith.edu.au/web/public-search/search/1240; and see Robinson, 239-45.

${ }^{21}$ NAA, B2455, Oldring Arthur Geoffrey.
} 
as a symptom of leadership or its weakness. His prejudice against Monash during the 1918 promotion controversy was mitigated by his view of the general's successful leadership of the 3rd Division, as reflected in its low crime rate. It was long known that the crime rate in the 3rd was very low compared to some of the other Australian units. In 1918 that reputation created the right kind of halo for Monash, whose "work with the third division is most visible still in the low - very low - percentage of their crime'. Contemporary data confirmed the picture (Table 1). ${ }^{22}$

\begin{tabular}{|c|c|c|c|c|c|c|c|c|c|c|c|}
\hline & Jan & Feb & Mar & Apr & May & Jun & Jul & Aug & Sep & Oct & Total \\
\hline 1st Division & 38 & 70 & 82 & 47 & 98 & 103 & 94 & 56 & 74 & 65 & 727 \\
\hline 2nd Division & 64 & 34 & 50 & 44 & 74 & 69 & 90 & 87 & 115 & 64 & 691 \\
\hline 3rd Division & 35 & 26 & 20 & 18 & 31 & 37 & 21 & 45 & 5 & 12 & 250 \\
\hline 4th Division & 32 & 45 & 59 & 43 & 91 & 100 & 86 & 71 & 98 & 88 & 713 \\
\hline 5th Division & 40 & 33 & 58 & 33 & 68 & 55 & 61 & 30 & 69 & 74 & 521 \\
\hline
\end{tabular}

Table 1: Number of convictions per Australian Division, Jan to Oct $1918^{23}$

Despite the wartime commentary on the association between the use of courts martial and related military efficiency and effectiveness, later literature commonly bypasses the role of courts martial in military administration. There are important exceptions, the product of more recent historiography, both in Australia and abroad. J. G. Fuller's 1990 study of military administration in the British and Dominion armies, as well as those of Germany, France and Italy, highlighted the variety of disciplinary modes as well as inter-rank relations in considering comparative troop morale. ${ }^{24}$ In much greater depth and crossing the entire span of New Zealand's role in World War I, Christopher Pugsley earlier examined the role of the court martial, its process and outcomes, including the application of the death penalty, the

\footnotetext{
${ }^{22}$ Bean cited in Geoffrey Serle, John Monash: A Biography (Melbourne: Melbourne University Press, 1982), 327.
}

${ }^{23}$ The figures were provided to Monash by the Adjutant-General 'to explain to Mr Hughes [Prime Minister] the position with reference to crime of the Australian divisions compared with the other divisions of the BEF'. Then Major Frank Officer, Deputy Assistant Adjutant General noted 'strong objection' to the figures being handed to Hughes lest they be used for political purposes although they might be sighted. AWM, Monash collection, RCDIG0000638, Officer to Monash (11 November 1918). Figures from January to June inclusive represent the number of men convicted. From July a new system records the number of court martial charges.

${ }^{24}$ J. G. Fuller, Troop Morale and Popular Culture in the British and Dominion Armies, 1914-1918 (Oxford: Clarendon Press, 1990), 50-52. 
uses of field punishment, and the role of imprisonment and other forms of detention in shaping soldiers' experience of the war. ${ }^{25}$ Blending some of the concerns with character and criminality that we have noted with a focus on the function of the court martial in military administration, Robert Stevenson recently highlighted the importance of the wartime debate over the discipline of Australian military units: the 'Bad Boy of the Imperial Family' as his chapter title has it. ${ }^{26}$ In a study of military leadership drawn from research on battalion commanders in the Australian Imperial Force (AIF), William Westerman has drawn attention to the significance of the court martial as an element of military discipline. ${ }^{27}$ Finally, in greater detail than any of these, Graham Wilson has also recently provided a detailed account of the military detention system in both world wars, an account informed by a close reading of military punishment records. ${ }^{28}$

Whether Australian crime and indiscipline undermined overall military effectiveness remains an open question. ${ }^{29}$ What is clear is that Australian soldiers were prosecuted in courts martial more frequently as the war extended, and at higher rates than other elements of the British Imperial forces. Australian forces were consistently much more likely to be prosecuted than the British, New Zealanders or Canadians, whether one looks at proportions prosecuted, rates of serious offences like desertion, and less serious ones like absenteeism. ${ }^{30}$ In contrast with the evidence for the British Expeditionary Force (BEF) and New Zealand divisions, the rate of courts martial relative to enlisted strength increased significantly in the Australian divisions in the final year of the war (Table 2). This is not to

\footnotetext{
${ }^{25}$ Pugsley.

${ }^{26}$ Stevenson, ch. 5.

${ }^{27}$ William Westerman, Soldiers and Gentlemen: Australian Battalion Commanders in the Great War, 19141918 (Melbourne: Cambridge University Press, 2017). See also Jean Bou and Peter Dennis, The Australian Imperial Force (Melbourne: Oxford University Press, 2016).

${ }^{28}$ Graham Wilson, Accommodating the King's Hard Bargain : Military Detention in the Australian Army 19141947 (Sydney: Big Sky Publishing, 2016).

${ }^{29}$ Ashley Kevin Ekins, 'Fighting to Exhaustion: Morale, Discipline and Combat Effectiveness in the Armies of 1918', in 1918 Year of Victory: The End of the Great War and the Shaping of History, ed. Ekins, 1st ed. (Wollombi: Exisle Publishing, 2010), 111-29.

${ }^{30}$ See especially Pugsley; Stevenson; Ekins. On other measures (e.g. involvement in large-scale disorder), other forces may have had less than exemplary records, as suggested by Wilson with respect to Canadian troops, $52-$ 3.
} 
gainsay the strong evidence from courts martial data (Table 1) that rates of prosecution also varied significantly among the various Australia divisions and battalions. ${ }^{31}$

\begin{tabular}{|l|r|r|r|r|r|r|r|r|r|r|}
\hline $\begin{array}{l}\text { Average no. of } \\
\text { convictions }\end{array}$ & Jan & \multicolumn{1}{|l|}{ Feb } & Mar & Apr & May & Jun & Jul & Aug & Sep & Oct \\
\hline UK Division & 21 & 22 & 16 & 13 & 20 & 19 & 21 & 21 & 19 & 15 \\
\hline $\begin{array}{l}\text { Australian } \\
\text { Division }\end{array}$ & 42 & 42 & 54 & 37 & 72 & 73 & 70 & 58 & 72 & 61 \\
\hline NZ division & 21 & 10 & 12 & 8 & 14 & 23 & 39 & 34 & 4 & 25 \\
\hline
\end{tabular}

Table 2: Comparison of court martial figures Jan to Oct $1918^{32}$

The use of courts martial accelerated throughout the war, with more than a third of Australian prosecutions occurring in the last year of the conflict, mainly on the Western Front. Even after cessation of hostilities, courts martial remained a critical element in military discipline, with at least 10 per cent of all Australian courts martial occurring in 1919 alone. The complex operation of demobilisation and the degree of insubordination on returning transports continued to cause disciplinary headaches for commanders. Some particularly egregious crimes were committed and prosecuted towards and after war's end, as we have noted in the discussion of the prosecution of William Banks for manslaughter. ${ }^{33}$ But heavy-handed use of courts martial ran the risk of aggravating tensions among the troops during the protracted period of demobilisation. As a recent study of the Australian Graves Detachment suggests, some commanding officers preferred to approach the problem of postwar indiscipline by

\footnotetext{
${ }^{31}$ D. B. Lambley, March in the Guilty Bastard (Burleigh MDC, Qld: Zeus Publications, 2012); Westerman.

32 AWM, Monash collection, RCDIG0000638.

${ }^{33}$ AWM, Ferguson collection, RCDIG0000038, Ferguson to Birdwood, letter (16 May 1919); Ferguson to Birdwood, letter (10 June 1919).
} 
attempting to raise morale through improving the provision of 'food, sports, entertainment and comfortable billeting', 34

To appreciate better the disciplinary options provided by the court martial, we have sampled 250 digitised files from series A471 in the National Archives of Australia (NAA), the holding archive of Australian courts martial proceedings. ${ }^{35}$ From these cases, we can examine circumstantial context as well as process and outcome characteristics, identifying offence, verdict and sentence qualified by the rank of the person charged. Though this sample only amounts to slightly more than one per cent of the total courts martial for this period, it is broadly representative. Officers comprise fifteen per cent of defendants, while 85 per cent are drawn from other ranks, mainly privates but including small numbers of troopers, sappers and drivers. ${ }^{36}$

\begin{tabular}{|c|c|c|c|c|c|c|c|}
\hline Year & 1914 & 1915 & 1916 & 1917 & 1918 & 1919 & Total \\
\hline All archival files & $\begin{array}{r}100 \\
(.45 \%)\end{array}$ & $\begin{array}{r}700 \\
(3.16 \%)\end{array}$ & $\begin{array}{r}3,342 \\
(15.1 \%)\end{array}$ & $\begin{array}{r}7,445 \\
(33.64 \%)\end{array}$ & $\begin{array}{r}8,060 \\
(36.42 \%)\end{array}$ & $\begin{array}{r}2,483 \\
(11.22 \%)\end{array}$ & 22,130 \\
\hline $\begin{array}{l}\text { Digitised files (at } \\
\text { Mar 2017) }\end{array}$ & $\begin{array}{r}10 \\
(.67 \%)\end{array}$ & $\begin{array}{r}67 \\
(4.48 \%)\end{array}$ & $\begin{array}{r}252 \\
(16.86 \%)\end{array}$ & $\begin{array}{r}483 \\
(32.31 \%)\end{array}$ & $\begin{array}{r}532 \\
(35.59 \%)\end{array}$ & $\begin{array}{r}151 \\
(10.1 \%)\end{array}$ & 1,495 \\
\hline $\begin{array}{l}\text { Prosecution Project } \\
\text { case sample }\end{array}$ & $\begin{array}{r}1 \\
(.4 \%)\end{array}$ & $\begin{array}{r}12 \\
(4.8 \%)\end{array}$ & $\begin{array}{r}36 \\
(14.4 \%)\end{array}$ & $\begin{array}{r}71 \\
(28.4 \%)\end{array}$ & $\begin{array}{r}113 \\
(45.2 \%)\end{array}$ & $\begin{array}{r}17 \\
(6.8 \%)\end{array}$ & 250 \\
\hline
\end{tabular}

Table 3: Comparison of Australian courts martial case samples, National Archives of Australia, A471

The major offence categories in the sample studied here were being absent without leave, desertion and mutiny (a sample bias, reflecting an unusually large number of prosecutions

\footnotetext{
${ }^{34}$ Romain Fathi, "We refused to work until we had better means for handling the bodies": Discipline at the Australian Graves Detachment', First World War Studies 9, no. 1 (2018): 40.

35 The almost comprehensive record series of courts martial proceedings, NAA, A471 includes 22,130 files for the years 1914-1919, some of them involving many co-accused. This data may be supplemented by the NAA, series A3193 'Name index cards for courts martial files [including war crimes trials], alphabetical series', and 'Nominal roll of court martial proceedings Australian Imperial Force', WO93/42, The National Archives (Kew). For the statistics, see especially Stevenson; Lambley. For a comparative view see also Pugsley.

${ }^{36}$ The proportion of prosecuted privates is consistent with analysis of prosecution by rank in Lambley, 12.
} 
associated with the collective protests against battalion disbandment in September 1918). ${ }^{37}$ Less frequent charges included disobeying orders, drunkenness and a range of criminal offences, including manslaughter, stealing and arson. The chief difference between ranks was in the charge of desertion which was not faced by any officer in this sample; and the offence of drunkenness, more likely to be faced by an officer than a private (whose infractions in this respect were most likely dealt with summarily by their superior officers). Officers were also more likely than privates to be acquitted, with the sample suggesting an acquittal rate of nearly 40 per cent compared with their subordinates who were found not guilty in less than one-in-ten cases.

These patterns are replicated in the distribution of penalties. Desertion was a very serious offence, faced only by privates in 250 courts martial with the death penalty sentence awarded against seven of those convicted, though never carried to execution. Other available sentences included shorter and longer terms of imprisonment up to life, detention and 'field punishments', and a reduction in rank or forfeiture of pay. Half of the officers found guilty received a penalty of rank reduction, although that was sometimes quickly reversed. ${ }^{38}$ Two thirds of privates convicted were sentenced to detention, field punishment or prison sentences; more than a quarter of them were sentenced to imprisonment sentences of more than two years (in this case the sample is also skewed by the inclusion of a disproportionately large number of cases associated with the 1st Battalion mutiny of September 1918). ${ }^{39}$

In military law, an important mitigating factor in outcome was the requirement that the sentence be confirmed by a senior officer, typically the judge-advocate charged with overseeing military justice. None of the capitally convicted soldiers was executed, in line with Australian policy. Many others, especially those initially sentenced to long-term imprisonment, had their sentences commuted or suspended in one way or another. The Australian Army was also exceptionally reluctant to impose the more severe Field Punishment 1 (binding to a fixed object in the outdoors for up to two hours a day). In our sample, dominated by sentences of imprisonment or short term detention (half the sample of

\footnotetext{
${ }^{37}$ Gammage, 229, 244-5.

${ }^{38}$ AWM, 3DRL/2379, Goddard collection, RCDIG0000799, army correspondence book entry (18 November 1917).

${ }^{39}$ Blair, 190-1. On the mutiny, see Nathan Wise, “In military parlance I suppose we were mutineers": Industrial Relations in the Australian Imperial Force during World War I', Labour History, 101 (2011): 161-76.
} 
those convicted), the lesser penalty of Field Punishment 2 (without the exemplary humiliation of restraint in public view) was three times more likely to be awarded than Field Punishment 1, the inverse of the position in the entire BEF. Imperial legislation in 1915 had mandated the suspension of sentences as a means of controlling the rate of imprisonment of those convicted, a reason for the widespread use of severe field punishment in other forces. But Australian reluctance to use such measures to keep men in active service meant that by late in the war Australian imprisonment rates were much higher than those of any other force. ${ }^{40}$

Perceptions of leniency in the application of available penalties dogged Australian debates at the highest command levels and was surely encouraged by the attitudes of some policy makers within the army. The extended debate through 1917 over the application of the death penalty highlighted the readiness of the Australians to reject the view that leniency would jeopardise the war effort. While explanation of this stance generally references Australian government perceptions that executing volunteer soldiers would jeopardise recruitment as well as scupper the possible success of a conscription referendum, opinion within the Australian army also played a role. ${ }^{41}$ Advising the Minister for Defence in February 1917, the Adjutant General Colonel Thomas Henry Dodds, a man with a reputation for supporting 'Australianisation' of the military, was exceptionally forthright in his views:

These are our troops and they are serving under our Defence Act. I am entirely opposed to the proposal that they should be brought under the Army Act without qualification. We are quite entitled to exclude from our Act any matters in the Army Act which the Australian Parliament may consider inadvisable. The inconsistencies in our Act cannot have any considerable effect in the matter of discipline. The maximum punishments allowed by our Act are sufficient to be a deterrent against the worst breaches of discipline. $^{42}$

\footnotetext{
${ }^{40}$ Geoff Barr, Military Discipline: Policing the 1st Australian Imperial Force 1914-1920 (Canberra: G. Barr, 2008), ch. 5, esp. pp. 70-1. The imperial legislation amending the Army Act was effected in the Australian forces by regulation, see Statutory Rules 1917, No. 62 Regulations under the Defence Act 1903-1915, https:/www.legislation.gov.au/Details/C1917L00062 and gazetted 7 March 1917 (http://nla.gov.au/nla.news-

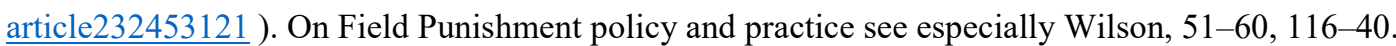

${ }^{41}$ The most comprehensive account remains that of Bean, who highlights the views of Pearce and Hughes along these lines in his Official History, 25-32, and esp. 29.

42 NAA, M367/1 403/8/354, Dodds to Secretary of Defence, minute (February 1917); for Dodds as one of the earliest proponents of ‘Australianisation' see A. J. Hill, 'Dodds, Thomas Henry (1873-1943), Australian Dictionary of Biography, National Centre of Biography, Australian National University,
} 
Translated into practice, leniency in penalties was viewed by those closer to operations with some alarm. 'There is a growing impression amongst the men throughout the AIF', observed Brigadier-General Henry Goddard in 1917, 'that no actual punishment will be inflicted for desertion and all suspended sentences will be annulled at the end of the war'. ${ }^{43}$ Late that year Birdwood proposed to Defence that the name of every man convicted on desertion be published in the press. 'A good many would I think dread this', he noted, anticipating a salutary effect. ${ }^{44}$ Thus, in mid-May 1918, the courts martial findings for two privates, respectively with 20th and 17th battalion, appeared in the Sydney Morning Herald. ${ }^{45}$ The Governor-General wrote to Birdwood announcing the publication.

As to Deserters and the question of publication of names, a statement appeared to the effect that some Australians have been a little remiss at times and that in future the names of such delinquents would be published. Two names have so far been black listed! ${ }^{46}$

Deprived of the severest sanctions of death and exemplary field punishment, the Australian authorities were left with the desperate resort of shaming. In that respect, discipline reached its limits, constrained by the politics that shaped the Australian application of military law.

\section{Law}

The very forms of the trial at court martial invoke standards of justice and fairness drawn from the norms of the civil law system. In 1916 Monash instructed his officers that the 'instinct of fairness' (more than leniency) should be the central consideration in the final judgement of any court-martial. ${ }^{47}$ As we suggested earlier, the relative lack of attention paid to the Australian court martial as a legal event may spring from the absence of the death penalty. It may also be a condition of the scholarly emphasis on the court martial as a function of discipline or an index of character rather than a long-standing legal institution, the

http://adb.anu.edu.au/biography/dodds-thomas-henry-5990, published first in hardcopy 1981 (accessed 2 March 2020).

${ }^{43}$ AWM, Goddard collection, RCDIG0000799, army correspondence book entry (11 November 1917).

${ }^{44}$ AWM, Ferguson collection, RCDIG0000041, Birdwood to Ferguson, letter (5 November 1917). Also Sydney Morning Herald, 14 May 1918, 7.

${ }^{45}$ Sydney Morning Herald, 14 May 1918, 7.

${ }^{46}$ AWM, Ferguson collection, RCDIG0000038, Ferguson to Birdwood, letter (2 June 1918).

${ }^{47}$ AWM, Monash collection, RCDIG0000615, Courts Martial Lecture to Presidents (24 September 1916). 
rules and particularities of which were followed with precision by Australian officers. ${ }^{48}$ Some of the major work on courts martial comes to us from jurisdictions where retrospective consideration of the justice of the death penalty in military theatres became a political matter decades after the war. This is especially the case for Britain, addressing a 1980s campaign for exoneration or pardon of those who had been executed. Anthony Babington's 1983 study of capital courts martial is the outstanding example here, though it is not isolated in the UK literature. ${ }^{49}$ Yet the focus of the British accounts on the death penalty has displaced attention to the broader military justice system. Paradoxically, the procedure at capital courts martial brought soldiers closer to the rights that civilians might enjoy in civil jurisdiction. At the same time, suggests Gerry Rubin, this leaves open the question of what kind of justice was exercised in the other 250,000 British proceedings. ${ }^{50}$

Despite relative neglect in Australia, research and resources enabling a focus on the court martial as a legal and regulatory institution have increased in recent years. Three important studies of the policing and judicial apparatus of World War I provide an indispensable foundation - one on military lawyers, another on military police, and a third on military detention. ${ }^{51}$ For all, the war was an occasion for institutional innovation. Alongside these institutional histories, we increasingly have ready access to a resource not available in Britain: the almost complete archive of courts martial proceedings. It is from there that we can recover the elements of process, performance and individual experience in the court martial as a legal event.

The court martial was inherited with Australia's colonial settlement. Nowhere is this clearer than in the overlapping authorities for conducting such a trial by the time of World War I. In the British imperial legacy, a court martial was a disciplinary tool; it was a

\footnotetext{
48 Wilson, 63-5.

${ }^{49}$ Babington; also Gerry Rubin, 'The Last Word on the Capital Court Martial Controversy in Britain? Towards a History of British Military Law in World War 1', in Jean-Marc Berlière, Jonas Campion, Luigi Lacchè and Xavier Rousseaux eds. Justices militaires et guerres mondiales (Europe 1914-1950) (Louvain-la-Neuve, Presses Universitaire de Louvain 2014), 39-56; Gerard Oram, 'The Administration of Discipline by the English Is Very Rigid: British Military Law and the Death Penalty (1868-1918)', Crime, Histoire \& Sociétés/Crime, History \& Societies 5, no. 1 (2001): 93-110.

${ }^{50}$ Rubin, 52.

${ }^{51}$ Bruce Oswald and Jim Waddell, eds, Justice in Arms: Military Lawyers in the Australian Army's First Hundred Years (Sydney: Big Sky Publishing, 2014); Glenn Wahlert, The Other Enemy? Australian Soldiers and the Military Police, Australian Army History Series (Melbourne: Oxford University Press, 1999); Wilson.
} 
proceeding set in motion by a commanding officer in a hierarchy surmounted by the governor of a colony. The translation of this arrangement into the new circumstance of an Australian federation meant by 1914 that the paramount authority in the military was the GovernorGeneral of the Commonwealth. With the enactment and later amendment of the first Defence Act 1903, military forces serving within or outside Australia were governed by the Imperial Army Act, unless the Defence Act or associated regulations provided otherwise. The power to constitute courts martial was laid out in the Defence Act, which provided that the GovernorGeneral might convene courts martial, appoint officers to constitute them and 'approve, confirm, mitigate, or remit the sentence of any court martial' ${ }^{52}$ The conduct of courts martial, including their 'composition, modes of procedure and powers', was as provided under the Army Act and the King's Regulations for the Army and Navy, but again with the reservation that the Australian Defence Act might provide otherwise. ${ }^{53}$

As much as courts martial lay within a structure of military administration, their form and features were a recognisable legacy of the common law. In 1923, with the experience of thousands of wartime trials behind him, the first Australian Judge Advocate General, Victor Le Gay Brereton, prepared a manual of courts martial procedure based heavily on 'principles of the common law, as applied in the procedure of civil courts of criminal jurisdiction'. Brereton pointed to the practice of higher courts as 'guidance as to what is best calculated to do justice' ${ }^{54}$ This norm was tested considerably in wartime experience on a battlefield.

As in the civil jurisdiction, there was a hierarchy of courts martial. ${ }^{55}$ The most serious offences would be tried before a General Court Martial (GCM) or a Field General Court Martial (FGCM) (only convened on active service when it was considered impracticable to hold a GCM). Other offences were tried before a District Court Martial

\footnotetext{
52 Defence Act 1903 (No. 20 of 1903), s86.

53 Ibid. s88.

${ }^{54}$ V. Le Gay Brereton, Courts Martial: Memoranda for the Assistance of Officers of the Australian Military Forces Convening Courts Martial ([Melbourne]: Adjutant-General's Branch, Army Headquarters, 1923), 3.

${ }^{55}$ For provisions governing courts martial see Great Britain War Office, Manual of Military Law (London, H M Stationery Office, 1907); and for British historical context generally see Clive Emsley, Soldier, Sailor, Beggarman, Thief: Crime and the British Armed Services since 1914 (Oxford: Oxford University Press, 2013). For the colonial background and early Commonwealth history, see Oswald and Waddell, 12-17; Albert Neil Preston, Military Law in Colonial Australia (Sydney: Federation Press, 2016); Wilson, chs 2-3.
} 
(DCM), or a Regimental Court Martial. ${ }^{56}$ The distinctions were characterised not only by the seriousness of offences, but by the punishments that might be awarded, and the persons who might be tried. Officers could be tried only before a General Court Martial or FGCM, in the relevant circumstance. District Courts Martial might award sentences of imprisonment for up to two years, while GCMs were the only tribunal empowered to award longer terms of imprisonment or the death penalty.

While acquittal was generally final, all convictions and associated sentences required confirmation by a superior officer, extending upwards to the King or governor of a colony (and so after 1903 the Governor-General of Australia). The burden of confirmation was considerable in circumstances where large numbers of cases - the great majority of those heard - required review and decision. ${ }^{57}$ One president with the 7 th Battalion recalled putting in a 'whole day' of 'arduous but interesting work' at a FGCM yet only managed to resolve five matters. ${ }^{58}$ Statutory requirements for retention of records, as provided in the Defence Act, make the Australian courts martial proceedings a remarkably intact archive. The civilian accountability of the military regime was signalled in this respect by the requirements that records be transmitted to the Attorney-General. ${ }^{59}$

As noted in the Manual of Military Law, there was a close connection between the different types of courts martial in terms of their personnel as well as their powers of punishment. ${ }^{60}$ The GCM had no fewer than five officers, sometimes up to nine; the others had at least three. None of the members of these courts could be of a rank lower than the person being tried. Each court was administered by a president appointed by the officer who had convened the court martial. A prosecutor brought the charges and the evidence before the court; at this time legal counsel for the defence was not permitted, although a 'friend' who might be a professional lawyer could support the person facing charges. In many respects the court martial at the time of World War I resembled the pre-professionalised character of civil

\footnotetext{
${ }^{56}$ For Solicitor-General Garran's summary of the position at 5 September 1914 (in communication with Brigadier-General Bridges), see NAA, M367/1 403/8/354. See also Stevenson, 109 for the system, which he characterises as one more akin to 'judicial tribunals'.

${ }^{57}$ Stevenson, 117.

58 AWM, PR04808, Tubb collection, RCDIG0000285, diary entry (30 October 1916).

${ }^{59}$ Defence Act 1903, s99(1).

${ }^{60}$ Manual of Military Law (1907), 36.
} 
law; and like the civil courts, it would, over the twentieth century, become more characteristically professional in its legal structure and proceedings.

Officers' understanding of the process and practice of courts martial was drawn from the British military literature, especially the Manual of Military Law, which was updated and published in 1914, while the AIF produced a local summary of the Army Act in $1916 .{ }^{61}$ A sense of the legal culture in which the officers would operate was captured by Monash in September 1916 when he addressed some of those who acted as presidents of courts martial in the newly formed Australian 3rd Division. His subject, he told his officers, was not military law or procedure but the exercise of the judicial function by members of such courts. The lecture was succinct in its delivery but wide-ranging and aspirational in its characterisation of the important role of the court martial as an element of discipline in a new division. That role, he argued, derived from the use of punishment as a deterrent, which would be functional for discipline to the extent that it was certain.

This utilitarian view of punishment informed Monash's insistence on the observance of procedural requirements including evidentiary proof and fairness of the process. The object of the court was to 'get out the truth', and the presidents were urged to resist a presumption of guilt in the absence of adequate evidence. The fact-finding responsibilities of the court grounded Monash's suggestion that in drawing a final judgement in a case (which, in most cases, would take no more than one hour in the field), the panellist's attitude must be that of a 'juryman'. Of course, the panel's task was more complex than a jury's since the court also exercised sentencing powers for those found guilty - and to this end it was important for presidents to discriminate between evidence as to the fact of guilt, which led to the verdict, and evidence affecting the degree of culpability, which shaped a calculation of sentence. Monash pointed to possible mitigating factors for sentencing, for example 'provocation, excitement, ignorance', the latter not an excuse but a possible extenuating circumstance. His lecture was notable for its reminder of how, even in the field of battle, the court martial was hedged around by legal norms that were considered as a

\footnotetext{
${ }^{61}$ Great Britain War Office, Manual of Military Law (London: H M Stationery Office, 1914); Brereton; Oswald and Waddell; AIF, Offences and Courts-Martial and Rules and Procedure of Courts-Martial. A Survey of the Provisions of the Army Act (Melbourne: Government Printer, 1916).
} 
'protection of the innocent against persecution or trumped up charges'. ${ }^{62}$ How far such a model was met in practice is a question for future research.

\section{Conclusion}

Courts martial were as essential to the operations of the Australian military machine in World War I as the general courts were in civil life. The policing of soldiers' behaviour and the administration of military justice are key elements of a modern military apparatus. Yet the Australian literature of World War I, an event saturated by memorialisation and historical writing, scarcely reflects this mundane reality. We have suggested some reasons for this, including the absence of the death penalty as a punishment for Australian military offences and the absence of concomitant political campaigns for retrospective pardoning or exoneration. While sustained research has been limited, courts martial form threads in the historical tapestry of World War I, especially in abiding concern about the character of individual soldiers and the AIF in general, as well as the role of military justice in army and navy discipline. In both respects, the evidence of courts martial serves as fodder in often polarised debates. The defence of the Anzac tradition shaped Bean's emphasis on the character of offenders as the failure of 'the few'. A demand to confront the influence of Anzac mythology with a realistic appraisal of the extent of character failings may be read in the contemporary revisionist literature that relies in part on the stories of those with whom military justice had to deal.

At a more collective level, the well-publicised criticism by army officers of Australian indiscipline, especially behind the lines, also drew on the courts martial. Thus Bean found reason to favour Monash's leadership in the lower 'crime' rates observed in the $3^{\text {rd }}$ Division compared to others, while others pondered the implications of an adverse comparison between the number of Australian courts martial prosecutions in 1918 and those of other forces. Military and civilian politics were equally in play as the Australians faced Army Council pressure to apply the death penalty, awarded in court martial proceedings against some Australian soldiers but never to the point of execution. Imperial demands for Australian legislative change or even executive action to ensure conformity with other

\footnotetext{
${ }^{62}$ AWM, Monash Collection, RCDIG0000615, Courts Martial Lecture (24 September 1916).
} 
elements of the British Expeditionary Force were met with resistance. Colonel Dodds may have been especially committed to a policy of 'Australianisation' in military command, but his forceful advocacy of autonomy in legislative matters demonstrates how this aspect of the war experience also served as a platform for expressions of Australian political identity. Enormous attention has been paid in the historical literature to the masculine construction of Australian nationalism associated with the Anzac experience and its memorialisation. But here we have something else - an assertion of Australian political autonomy being worked out in the interstices of wartime government.

Finally, missing for the most part from the Australian historiography is the study of the courts martial as a court, as a proceeding subject to law, and the specific demands of military justice. The modern reform of military justice has brought it even closer to the modes of civilian justice. ${ }^{63}$ In reviewing the possibilities of a study that might address the subject from this perspective, we have highlighted the potential of a comprehensive study of digitised and linked Australian courts martial data. Rather than the court martial archive being a residual embarrassment calling into question the character of Australian troops or otherwise simply the legacy record of discipline as an element of the war apparatus, such an approach seeks to highlight the legal process and justice concerns of what was after all a court, however exceptional its jurisdiction.

\section{Mark Finnane}

Griffith University

Email: m.finnane@,griffith.edu.au

ORCID 0000-0003-3776-8091

Yorick Smaal

Griffith University

Email:y.smaal@griffith.edu.au

\footnotetext{
${ }^{63}$ Rain Liivoja, 'Military Justice', in The Oxford Handbook of Criminal Law, eds Markus D. Dubber and Tatjana Hörnle (Oxford: Oxford University Press 2014); Alison Duxbury and Matthew Groves, eds Military Justice in the Modern Age (Cambridge: Cambridge University Press, 2016); Gerard Oram, “"The Greatest Efficiency": British and American Military Law, 1866-1918', in Comparative Histories of Crime, ed. Clive Emsley, Graeme Dunstall, and Barry S. Godfrey (Cullompton: Willan Publishing, 2003), 159-77. But cf. on its exceptionalism see David H. Denton, 'The Australian Military Justice System: History, Organisation and Disciplinary Structure', Victoria University Law and Justice Journal 6, no. 1 (2017): 26, https://doi.org/10.15209/vulj.v6i1.1059 (accessed 29 Jul 2019).
} 